\title{
Enterococci used as complementary \\ indicator of fecal contamination to assess \\ water quality from public schools in the city \\ of Curitiba, Paraná, Brazil
}

\section{Enterococos como indicador complementar de contaminação fecal para avaliar a qualidade da água de escolas na cidade de Curitiba, Paraná, Brasil}

\author{
Mariana Amabile Waideman'1, Vivian Plaça Teixeira', Elisa Hizuru Uemura², \\ Tânia Montenegro Stamford ${ }^{3}$, Diego Averaldo Guiguet Leal ${ }^{2}$, Lize Stangarlin-Fiori ${ }^{1 *}$ (i), \\ Sila Mary Rodrigues Ferreira ${ }^{1}$, César Augusto Taconeli ${ }^{4}$, Márcia Regina Beux ${ }^{1}$ (D)
}

\author{
${ }^{1}$ Universidade Federal do Paraná (UFPR), Departamento de Nutrição, Programa de Pós-graduação em \\ Alimentação e Nutrição, Curitiba/PR - Brasil \\ ${ }^{2}$ Universidade Federal do Paraná (UFPR), Departamento de Patologia Básica, Programa de Pós-graduação em \\ Microbiologia, Parasitologia e Patologia, Curitiba/PR - Brasil \\ ${ }^{3}$ Universidade Federal de Pernambuco (UFPE), Departamento de Nutrição, Programa de Pós-graduação em \\ Nutrição, Recife/PE - Brasil \\ ${ }^{4}$ Universidade Federal do Paraná (UFPR), Departamento de Estatística, Curitiba/PR - Brasil
}

${ }^{*}$ Corresponding Author: Lize Stangarlin-Fiori, Universidade Federal do Paraná (UFPR), Av. Lothário Meissner, 632, Jardim Botânico, CEP: 80210-170, Curitiba/PR - Brasil, e-mail: lizestangarlin@hotmail.com

Cite as: Waideman, M. A., Teixeira, V. P., Uemura, E. H., Stamford, T. M., Leal, D. A. G., Stangarlin-Fiori, L., Ferreira, S. M. R., Taconeli, C. A., \& Beux, M. R. (2020). Enterococci used as complementary indicator of fecal contamination to assess water quality from public schools in the city of Curitiba, Paraná, Brazil. Brazilian Journal of Food Technology, 23, e2019155. https://doi.org/10.1590/1981-6723.15519

\begin{abstract}
The study evaluated the drinking water quality from 45 public schools in the city of Curitiba, Brazil. Water samples were harvested from two different points at each school: the first one, drinking fountain used by students $(n=45)$ and the second, kitchen faucet $(n=45)$, comprising 90 samples. The samples were submitted to analysis according to current legislation, such as: dosage of free chlorine; colony counts of heterotrophic bacteria; presence of total coliform bacteria and Escherichia coli. In addition, an enterococci analysis was also included as a complementary microbiological indicator of fecal contamination. The isolated strains of enterococci were identified and submitted to an antibiotic susceptibility test. In relation to the legal parameters, $35.5 \%(n=16)$ of the 45 schools evaluated did not meet the quality water standards set by the Brazilian legislation. Although none of the 90 samples exhibited the presence Escherichia coli, $6.6 \%(n=6)$ of the analyzed samples presented enterococci contamination. Regarding the antibiotic susceptibility test, the isolated strains demonstrated a similar behavior, became resistant to six antibiotics and had intermediate sensitivity to one (Streptomycin) of the nine antibiotics tested. The drinking water destined for human consumption in the public schools may pose health risks for students since the fecal contamination by enterococci was confirmed, and it could be observed that the water may be a source of genes from bacteria resistant to antimicrobials. This study reinforces the importance of monitoring complementary microbiological indicators to
\end{abstract}


assure water quality, seeing that fecal contamination was detected only when alternative parameters were inserted, emphasizing the relevance of including microbiological indicators beyond what the legislation requires to evaluate the drinking water more effectively and to safeguard public health.

Keywords: Quality control; Water microbiology; Drinking water; Water quality; Sanitary inspection; Health legislation.

\section{Resumo}

O estudo avaliou a qualidade da água potável de 45 escolas públicas na cidade de Curitiba, Brasil. Amostras de água foram coletadas de dois pontos diferentes de cada escola: o bebedouro utilizado pelos alunos $(n=45)$ e a torneira da cozinha $(n=45)$, totalizando 90 amostras. As amostras foram submetidas à análise de parâmetros legais: dosagem de cloro livre, contagem de bactérias heterotróficas, presença de coliformes totais e Escherichia coli. Além disso, a análise de enterococos também foi incluída como um indicador microbiológico complementar de contaminação fecal. As cepas de enterococos isolados foram identificadas e submetidas ao teste de sensibilidade a antibióticos. Em relação aos parâmetros legais, 35,5\% $(n=16)$ das 45 escolas avaliadas não atenderam aos padrões de qualidade da água da legislação brasileira. Embora nenhuma das 90 amostras exibisse a presença de Escherichia coli, observou-se que $6,6 \%(n=6)$ das amostras analisadas apresentaram contaminação por enterococos. No teste de sensibilidade aos antibióticos, as cepas isoladas demonstraram um comportamento semelhante, apresentando resistência a seis antibióticos e sensibilidade intermediária a um (estreptomicina). A água potável destinada ao consumo humano nas escolas públicas pode representar um risco à saúde dos estudantes, uma vez que a contaminação fecal por enterococos foi confirmada e considerada uma fonte de genes com resistência a antimicrobianos que podem ser facilmente disseminados para outras pessoas. Este estudo reforça a importância do monitoramento de indicadores microbiológicos complementares para garantir a qualidade da água, uma vez que a contaminação fecal foi detectada apenas quando parâmetros alternativos foram inseridos, enfatizando sua relevância para avaliar a água de maneira mais eficaz e salvaguardar a saúde pública.

Palavras-chave: Controle de qualidade; Microbiologia da água; Água potável; Qualidade da água; Inspeção sanitária; Legislação sanitária.

\section{Introduction}

The lack of safe drinking water prevents the daily hygiene practices and may compromise not only students' health, but also their educational performance (Morgan et al., 2017). Thus, the waterborne outbreaks associated with drinking water contamination is related to a global public health concern (Park et al., 2018), particularly in the school environment (World Health Organization, 2015a).

Foodborne diseases are caused by the consumption of contaminated food or water. It is noteworthy that, worldwide, there are still approximately 663 million people without access to drinking water. About 2 million of the annual deaths involving individuals under five years old are also related to waterborne diseases (World Health Organization, 2015b).

Infection may be a result of human and animal fecal contaminations within the entire water supply system (Wallender et al., 2014). According to Braeye et al. (2015), water is one of the most common transmission routes of enteric pathogens and fecal contamination. This infection results from inadequate conditions, such as low residual chlorine concentration and when water supply pipes break (Ashbolt, 2015).

The contact with contaminated water, however, does not only occur in households. In schools, water is used to be thirst-quenching, to prepare food and to use in personal hygiene. If drinking water is not safe, this supply can transport pathogenic microorganisms, which represents a health risk for students, teachers, and staff (Rahman et al., 2016). 
Several countries have reported outbreaks of gastroenteritis transmitted by contaminated water, affecting school-aged children (Rahman et al., 2016). For example, an outbreak could be noted at an educational institution in Ghana. Ameme et al. (2016) confirmed that contaminated water was the transmission route for the outbreak of gastroenteritis on that occasion. The water used by students in South Korea was likewise related to an outbreak in which 188 individuals exhibited symptoms of gastroenteritis (Park et al., 2018).

In Brazil, the epidemiological profile of waterborne diseases is still poorly understood, especially due to the underreporting of sporadic cases or waterborne outbreaks triggered by several other etiologies. In addition, according to the data from the Ministry of Health, there were 6,809 outbreaks of foodborne diseases recorded from 2009 to 2018 in Brazil, provided that water was considered one of the main responsible nutrients, being accountable for $21.1 \%$ of the outbreaks (Brasil, 2019).

The monitoring, removal and inactivation of waterborne pathogens and bacteriological indicators of fecal contamination are considered critical for water production systems around the world (Ikonen et al., 2017). The adequacy criteria of these features in the school environment also seem to be questionable (Marzano \& Balzaretti, 2013; Morgan et al., 2017). According to Ngwenya et al. (2018), the fragility of water facilities and drinking water provision in Brazilian schools was reinforced by the low priority owing to the monitoring and improvement of these items, even though this is considered a key aspect of public health intervention.

Thus, it seems necessary to define systematic monitoring and to implement preventive strategies for water quality management in educational institutions to prevent and control waterborne disease outbreaks (Park et al., 2018). The quality of drinking water sources must ensure the safety of drinking-water supplies by the assessment of legal indicators, such as dosage of free residual chlorine, presence of total coliform bacteria and Escherichia coli (E. coli) as well as colony counts of heterotrophic bacteria (Brasil, 2017).

In addition to these legal indicators, the World Health Organization (WHO) also recommends the use of complementary microbiological indicators, such as intestinal enterococci, to assess drinking water quality (World Health Organization, 2018). However, as could be seen, no study has been found to evaluate the use of this complementary indicator for the assessment of drinking water in schools. Therefore, this study intended to assess the drinking water quality in schools by using legal indicators and complementary microbiological indicators of fecal contamination, and to evaluate the resistance of the isolated strains to antibiotics.

\section{Material and methods}

\subsection{Study design}

This research consisted of a cross-sectional, observational, and analytical study of the drinking water of public schools in the city of Curitiba, in the state of Paraná, Brazil. According to the majority of the 199 public schools, attended by 40,649 students, drinking water came from the kitchen tap or from drinking fountains installed in schools. However, only 85 institutions had drinking fountains in 2014, the year in which the survey was conducted, according to information from the "State Department of Education of Paraná". Therefore, to collect the water regarding two drinking water consumed by students, only schools that had drinking fountains were selected for the present study. To constitute the sample, 45 schools were chosen randomly among these institutions. The margin of error of $10 \%$ was considered, comprising a confidence level of 0.95 and respected the proportionality of the nine sectors of the city of Curitiba.

\subsection{Collection of samples}

During this period, by the year 2014, aliquots of $250 \mathrm{~mL}$ of water were collected from two points of each school: the drinking fountain used by students $(\mathrm{n}=45)$ and the kitchen faucet $(\mathrm{n}=45)$, totaling 90 samples. The collection procedure followed the protocol of the Standard Methods for the Examination of Water and 
Wastewater (American Public Health Association, 2012). In addition, to remove impurities and buildup in drains and plumbing fixtures, the collection sites had been previously sprayed with $70 \%$ alcohol for disinfection and the water left running for three minutes.

While the dosage of free chlorine was carried out on each site, the other analysis (colony counts of heterotrophic bacteria; presence of total coliform bacteria and E. coli) was carried out in water collected in sterile flasks containing a tablet of sodium thiosulfate (Idexx, São Paulo, Brazil) to neutralize any residual chlorine. After harvesting, the samples were identified, packed in isothermal boxes containing ice and transported to the laboratory for analysis. The time between the collection and the beginning of the analyses did not exceed 24 hours (American Public Health Association, 2012).

\subsection{Assessment of legal indicators of drinking water quality}

The assessment of drinking water quality according to the legal parameters of collected water samples (Brasil, 2017) was carried out by determining the amount of free residual chlorine, the presence of total coliform bacteria and E. coli and counts of heterotrophic bacteria. For this purpose, the amount of free residual chlorine was determined as prescribed by the Standard Methods for the Examination of Water and Wastewater (American Public Health Association, 2012).

\subsection{Free residual chlorine}

After collecting the aliquots of water, the dosage of free residual chlorine was verified through a colorimetric test (Genco, São Paulo, Brazil), according to the manufacturer instructions. Briefly, the water was poured to the indicated level in a flask and four drops of ortho-tolidine (o-tolidine) reagent was added to the material. The vessel was closed and vigorously shaken to homogenize the material, and to acquire a homogeneous color; after that, this content was compared to a standard $\mathrm{pH}$ indicator positioned on the side of the container, that indicated if the water analysis was in accordance with the results according to the minimum standard of $0.2 \mathrm{mg} / \mathrm{L}$ (Brasil, 2017; World Health Organization, 2018).

\subsection{Total coliform and Escherichia coli}

During the assessment of drinking water quality, the total coliform test was performed using the presence/absence test (P/A) with Colilert ${ }^{\circledR}$ substrate (Idexx, São Paulo, Brazil). The contents of one Colilert ${ }^{\circledR}$ blister pack were added to a $100 \mathrm{~mL}$ water sample, slightly shaken, and incubated at $35^{\circ} \mathrm{C}$ to $37{ }^{\circ} \mathrm{C}$ for 24 hours. After incubation, the flasks were visually observed and those presenting a yellowish coloration were positive for total coliforms (American Public Health Association, 2012). The flasks that were positive for total coliforms were exposed to ultraviolet light emission of wavelength $360 \mathrm{~nm}$, and those that showed fluorescence were considered positive for E. coli as well (American Public Health Association, 2012). The interpretation of the results, concerning to total coliforms and E. coli, followed the Brazilian legislation (Brasil, 2017) and the World Health Organization (2018), which recommend the absence of these microorganisms in, at least, $100 \mathrm{~mL}$ of water (Brasil, 2017; World Health Organization, 2018).

\subsection{Heterotrophic bacteria}

In addition, heterotrophic bacteria were counted using an enzyme substrate method known as the SimPlate for Heterotrophic Plate Count (HPC) method (Idexx, São Paulo, Brazil). The interpretation of the results used the specification of $500 \mathrm{CFU} / \mathrm{mL}$ (Brasil, 2017; World Health Organization, 2018). 


\subsection{Assessment of the complementary indicator}

The assessment of the complementary indicator, regarding the enterococci, was carried out using the Presence/Absence (P/A) test with an Enterolert ${ }^{\circledR}$ substrate (Idexx, São Paulo, Brazil) (American Public Health Association, 2012). The interpretation of the results followed the European Community standard specification, indicating absence of microorganisms (Council of the European Union, 1998). Samples that were positive for enterococci were submitted to biochemical identification and to the Kirby-Bauer test for antibiotic susceptibility, in which the following antibiotics were tested: ciprofloxacin $(5 \mu \mathrm{g})$; chloramphenicol $(30 \mu \mathrm{g})$; erythromycin $(15 \mu \mathrm{g})$; penicillin $(10 \mu \mathrm{g})$; rifampicin $(5 \mu \mathrm{g})$; tetracycline $(30 \mu \mathrm{g})$; ampicillin $(10 \mu \mathrm{g})$; gentamicin $(120 \mu \mathrm{g})$ and streptomycin $(300 \mu \mathrm{g})$. The classification of the results - sensitive, intermediate, or resistant - was made by measuring the inhibition zone in millimeters by using a pachymeter (Clinical and Laboratory Standards Institute, 2011).

\subsection{Interpretation of results}

The results for each parameter analyzed, i.e., the content of free residual chlorine, total coliforms, E. coli, enterococci and count of heterotrophic bacteria were classified as adequate (A), when they met the established specification, and as inadequate (I), when they did not. Subsequently, the samples were classified as "Proper", when all parameters were adequate, or "Inappropriate", when any of the parameters were inadequate.

\section{Results and discussion}

This study showed that $35.5 \%$ ( $\mathrm{n}=16)$ of the 45 schools evaluated did not meet the quality standards for drinking water. Regarding the institutions with irregularities, $37.5 \%(\mathrm{n}=6)$ presented non-standard characteristics in both samples of water (kitchen faucets and drinking fountains); whereas, $37.5 \%(n=6)$ presented non-standard characteristics only in the water used in kitchen faucets and $25 \%(n=4)$ in the water of drinking fountains (Table 1).

In the assessment of the legal standards, the dosage of free residual chlorine was verified to be non-standard in $17.7 \%(n=16)$ of the 90 samples evaluated, in which seven samples were taken from kitchen faucets and nine were corresponded to the water of drinking fountains. The presence of total coliforms was detected in $6.6 \%(\mathrm{n}=6)$ of the analyzed samples, being detected in five samples of the water of kitchen faucets and one in the water of drinking fountains. Furthermore, heterotrophic bacteria were found in $8.8 \%(n=8)$ of the samples, three samples in the water of kitchen faucets and five in the water of drinking fountains (Table 1).

Table 1. Public schools with a supply of water samples from kitchen faucets or drinking fountains considered unsafe; and number of students affected, Curitiba, Brazil.

\begin{tabular}{|c|c|c|c|c|c|c|c|c|c|}
\hline \multirow[b]{2}{*}{ School } & \multicolumn{5}{|c|}{ Legal Parameters } & \multicolumn{3}{|c|}{ Complementary Microbiological indicator } & \multirow{2}{*}{$\begin{array}{l}\text { Number } \\
\text { of } \\
\text { students } \\
\text { affected }\end{array}$} \\
\hline & $\begin{array}{c}\text { Collection } \\
\text { area }\end{array}$ & Chlorine & T.C. & E. coli & $\begin{array}{c}\text { Heterotrophic } \\
\text { bacteria }\end{array}$ & $\begin{array}{l}\text { Partial } \\
\text { Result }\end{array}$ & Enterococci & $\begin{array}{l}\text { Partial } \\
\text { Result }\end{array}$ & \\
\hline \multirow{2}{*}{1} & $\begin{array}{l}\text { Kitchen } \\
\text { faucet }\end{array}$ & A & A & A & A & Proper & A & Proper & \multirow{2}{*}{435} \\
\hline & $\begin{array}{l}\text { Drinking } \\
\text { fountain }\end{array}$ & I & A & A & A & Inappropriate & A & Proper & \\
\hline \multirow{2}{*}{2} & $\begin{array}{l}\text { Kitchen } \\
\text { faucet }\end{array}$ & I & A & A & A & Inappropriate & A & Proper & \multirow{2}{*}{506} \\
\hline & $\begin{array}{l}\text { Drinking } \\
\text { fountain }\end{array}$ & I & A & A & I & Inappropriate & A & Proper & \\
\hline
\end{tabular}


Enterococci used as complementary indicator of fecal contamination to assess water quality from public schools in the city of Curitiba, Paraná, Brazil

Waideman, M. A. et al.

Table 1. Continued...

\begin{tabular}{|c|c|c|c|c|c|c|c|c|c|}
\hline \multirow{2}{*}{ School } & \multicolumn{5}{|c|}{ Legal Parameters } & \multicolumn{3}{|c|}{ Complementary Microbiological indicator } & \multirow{2}{*}{$\begin{array}{c}\text { Number } \\
\text { of } \\
\text { students } \\
\text { affected }\end{array}$} \\
\hline & $\begin{array}{c}\text { Collection } \\
\text { area }\end{array}$ & Chlorine & T.C. & E. coli & $\begin{array}{c}\text { Heterotrophic } \\
\text { bacteria }\end{array}$ & $\begin{array}{l}\text { Partial } \\
\text { Result }\end{array}$ & Enterococci & $\begin{array}{l}\text { Partial } \\
\text { Result }\end{array}$ & \\
\hline \multirow{2}{*}{3} & $\begin{array}{l}\text { Kitchen } \\
\text { faucet }\end{array}$ & A & I & A & A & Inappropriate & A & Proper & \multirow{2}{*}{2,236} \\
\hline & $\begin{array}{l}\text { Drinking } \\
\text { fountain }\end{array}$ & A & A & A & A & Proper & A & Proper & \\
\hline \multirow{2}{*}{5} & $\begin{array}{l}\text { Kitchen } \\
\text { faucet }\end{array}$ & I & A & A & A & Inappropriate & A & Proper & \multirow{2}{*}{505} \\
\hline & $\begin{array}{l}\text { Drinking } \\
\text { fountain }\end{array}$ & I & A & A & A & Inappropriate & A & Proper & \\
\hline \multirow{2}{*}{8} & $\begin{array}{l}\text { Kitchen } \\
\text { faucet }\end{array}$ & A & A & A & I & Inappropriate & A & Proper & \multirow{2}{*}{324} \\
\hline & $\begin{array}{l}\text { Drinking } \\
\text { fountain }\end{array}$ & A & A & A & A & Proper & A & Proper & \\
\hline \multirow{2}{*}{10} & $\begin{array}{l}\text { Kitchen } \\
\text { faucet }\end{array}$ & I & A & A & I & Inappropriate & A & Proper & \multirow{2}{*}{914} \\
\hline & $\begin{array}{l}\text { Drinking } \\
\text { fountain }\end{array}$ & I & A & A & A & Inappropriate & I & $\begin{array}{l}\text { Inappropr } \\
\text { iate }\end{array}$ & \\
\hline \multirow{2}{*}{12} & $\begin{array}{l}\text { Kitchen } \\
\text { faucet }\end{array}$ & A & A & A & A & Proper & A & Proper & \multirow{2}{*}{1,395} \\
\hline & $\begin{array}{l}\text { Drinking } \\
\text { fountain }\end{array}$ & I & A & A & A & Inappropriate & A & Proper & \\
\hline \multirow{2}{*}{14} & $\begin{array}{l}\text { Kitchen } \\
\text { faucet }\end{array}$ & A & I & A & A & Inappropriate & A & Proper & \multirow{2}{*}{821} \\
\hline & $\begin{array}{l}\text { Drinking } \\
\text { fountain }\end{array}$ & A & A & A & A & Proper & I & $\begin{array}{l}\text { Inappropr } \\
\text { iate }\end{array}$ & \\
\hline \multirow{2}{*}{16} & $\begin{array}{l}\text { Kitchen } \\
\text { faucet }\end{array}$ & I & A & A & I & Inappropriate & I & $\begin{array}{l}\text { Inappropr } \\
\text { iate }\end{array}$ & \multirow{2}{*}{1,217} \\
\hline & $\begin{array}{l}\text { Drinking } \\
\text { fountain }\end{array}$ & I & A & A & I & Inappropriate & I & $\begin{array}{l}\text { Inappropr } \\
\text { iate }\end{array}$ & \\
\hline \multirow{2}{*}{17} & $\begin{array}{l}\text { Kitchen } \\
\text { faucet }\end{array}$ & A & I & A & A & Inappropriate & I & $\begin{array}{l}\text { Inappropr } \\
\text { iate }\end{array}$ & \multirow{2}{*}{513} \\
\hline & $\begin{array}{l}\text { Drinking } \\
\text { fountain }\end{array}$ & A & A & A & A & Proper & A & Proper & \\
\hline \multirow{2}{*}{18} & $\begin{array}{l}\text { Kitchen } \\
\text { faucet }\end{array}$ & A & A & A & A & Proper & A & Proper & \multirow{2}{*}{1,851} \\
\hline & $\begin{array}{l}\text { Drinking } \\
\text { fountain }\end{array}$ & A & A & A & I & Inappropriate & A & Proper & \\
\hline \multirow{2}{*}{20} & $\begin{array}{l}\text { Kitchen } \\
\text { faucet }\end{array}$ & A & I & A & A & Inappropriate & A & Proper & \multirow{2}{*}{2,112} \\
\hline & $\begin{array}{l}\text { Drinking } \\
\text { fountain }\end{array}$ & A & A & A & A & Proper & A & Proper & \\
\hline 39 & $\begin{array}{l}\text { Kitchen } \\
\text { faucet }\end{array}$ & I & A & A & A & Inappropriate & I & $\begin{array}{l}\text { Inappropr } \\
\text { iate }\end{array}$ & 863 \\
\hline
\end{tabular}


Enterococci used as complementary indicator of fecal contamination to assess water quality from public schools in the city of Curitiba, Paraná, Brazil

Waideman, M. A. et al.

Table 1. Continued...

\begin{tabular}{|c|c|c|c|c|c|c|c|c|c|}
\hline \multirow{3}{*}{ School } & \multicolumn{5}{|c|}{ Legal Parameters } & \multicolumn{3}{|c|}{ Complementary Microbiological indicator } & \multirow{3}{*}{$\begin{array}{l}\text { Number } \\
\quad \text { of } \\
\text { students } \\
\text { affected }\end{array}$} \\
\hline & $\begin{array}{l}\text { Collection } \\
\text { area }\end{array}$ & Chlorine & T.C. & E. coli & $\begin{array}{c}\text { Heterotrophic } \\
\text { bacteria }\end{array}$ & $\begin{array}{l}\text { Partial } \\
\text { Result }\end{array}$ & Enterococci & $\begin{array}{l}\text { Partial } \\
\text { Result }\end{array}$ & \\
\hline & $\begin{array}{l}\text { Drinking } \\
\text { fountain }\end{array}$ & I & I & $\mathrm{A}$ & I & Inappropriate & $\mathrm{A}$ & Proper & \\
\hline \multirow{2}{*}{41} & $\begin{array}{c}\text { Kitchen } \\
\text { faucet }\end{array}$ & I & A & A & A & Inappropriate & A & Proper & \multirow{2}{*}{1,366} \\
\hline & $\begin{array}{l}\text { Drinking } \\
\text { fountain }\end{array}$ & A & A & A & A & Proper & A & Proper & \\
\hline \multirow{2}{*}{44} & $\begin{array}{l}\text { Kitchen } \\
\text { faucet }\end{array}$ & I & I & A & A & Inappropriate & A & Proper & \multirow{2}{*}{1,192} \\
\hline & $\begin{array}{l}\text { Drinking } \\
\text { fountain }\end{array}$ & I & A & A & A & Inappropriate & A & Proper & \\
\hline \multirow{2}{*}{45} & $\begin{array}{c}\text { Kitchen } \\
\text { faucet }\end{array}$ & A & A & A & A & Proper & A & Proper & \multirow{2}{*}{828} \\
\hline & $\begin{array}{l}\text { Drinking } \\
\text { fountain }\end{array}$ & I & A & A & I & Inappropriate & A & Proper & \\
\hline
\end{tabular}

Chlorine: A (adequate) = higher than $0.2 \mathrm{mg} / \mathrm{mL}$; I (inadequate) $=$ lower than $0.2 \mathrm{mg} / \mathrm{mL}$; T.C.: Total Coliforms: $\mathrm{I}=$ present, $\mathrm{A}=$ absent; E. coli: $\mathrm{I}=$ present, $\mathrm{A}=$ absent; Heterotrophic bacteria: $\mathrm{I}$ (inadequate) = higher than $500 \mathrm{CFU}, \mathrm{A}$ (adequate) = lower than $500 \mathrm{CFU}$; Enterococci: $\mathrm{I}($ inadequate $)=$ present, $\mathrm{A}$ (adequate) $=$ Absent; Proper: when presenting all parameters as A (adequate); Inappropriate: when presenting any parameter as I (inadequate).

With respect to the analysis of free residual chlorine, total coliforms, and heterotrophic bacteria, it could be noted that the irregularities in schools may be related to water that remains in the pipes for 24 hours a day. This result may be linked to the depletion of residues and to exposure of biofilms presented in water fountains and kitchen faucets. These factors contribute to the microbial growth and to considerable changes in the concentration and composition of the water (Proctor \& Hammes, 2015). These results were similar to those found in other studies, which have also analyzed the water in school settings (Marzano \& Balzaretti, 2013; Rahman et al., 2016) and revealed the need to reevaluate the quality of this resource.

The presence of heterotrophic bacteria in some water samples is sometimes related to the presence of pathogenic indicators. This present is due to these microorganisms that are currently used as indicators of the overall quality of water in the entire supply system. These bacteria are an important tool in the operational guidelines for monitoring as indicators of treatment, cleaning, and disinfection of the entire water supply system (Marzano \& Balzaretti, 2013; World Health Organization, 2018). Thus, high scores of these microorganisms may indicate failure of disinfection, biofilm formation, failures in the storage and/or distribution systems and the presence of Organic Matter (OM) in the water (Diduch et al., 2016).

Some studies demonstrated the presence of the coliform group in school water systems (Sanches et al., 2015; Meschede et al., 2018). These microorganisms are divided into two groups, total and fecal coliforms. Total coliforms comprise Enterobacteriaceae species belonging to the genera Klebsiella, Enterobacter, Citrobacter and E. coli (American Public Health Association, 1998). The group of fecal coliforms is a subgroup of total coliforms and is restricted to E. coli, as its primary habitat is human and animal gastrointestinal tract. The other bacteria, Citrobacter, Enterobacter and Klebsiella, are present in different ecosystems and can also be present in animal manure, soil and even submerged wood (Feng et al., 2002; United States Environmental Protection Agency, 2019).

Total coliforms are usually used for monitoring the effect of water chlorination (Said et al., 2015; Brasil, 2017). Thus, water chlorination is considered an important process in the treatment of drinking water for 
disease prevention. This process results from the reactions of chlorine with ammonia, iron, magnesium, sulfate and some organic substances and serves to destroy, inhibit the infectivity or remove a wide range of microorganisms and contributes to the quality of the water (Chowdhury, 2012; Marzano \& Balzaretti, 2013). According to its many different chemical formulations, free residual chlorine is widely used for the disinfection of water and is necessary to maintain a minimum concentration of $0.2 \mathrm{mg} / \mathrm{L}$ (Brasil, 2017; World Health Organization, 2018) in the entire water supply system to enable the elimination of possible pathogens.

Total coliforms could be detected in our study, even in samples with adequate free chlorine content in drinking water (Table 1). These results were also reported in another study (Fakayode \& Ogunjobi, 2018), and may be related to the ability of these indicator microorganisms to resist chlorine, allowing their survival and persistence in water distribution systems, even after cleaning and disinfection procedures have been performed.

According Bishankha etal. (2013) bacteria developed chlorine resistance owing to structural modifications on the cell surface that can lead to increased microbial adhesion to surfaces or suspended particulate matter. Under these circumstances, the resistance of total coliforms to disinfectants may cause them inefficient regarding water quality assessments in schools.

Moreover, if the results obtained after the evaluation of the legal parameters had been the only ones considered in this study, the hypothesis of fecal contamination would have been discarded, since there was no detection of $E$. coli in these samples. Nevertheless, the presence of enterococci was detected in $6.6 \%$ of the water of 90 samples analyzed (Table 1).

Water contamination by enterococci in schools does not suggest that the water is not in accordance with national quality standards, as Brazilian legislation does not establish regulations for this parameter (Brasil, 2017). However, most water samples that contained enterococci $(83.33 \%, \mathrm{n}=5)$, were also inadequate in relation to the analysis of chlorine or other microbiological parameters (Table 1). This result may indicate possible hazards according to the water quality of these schools, regardless of not meeting the water quality standards of Brazilian legislation, these samples also contained enterococci.

Enterococci tests can be a useful tool to complement the indicators of safe water, as they are more resistant to chemical agents (such as chlorine) (D’Ugo et al., 2018), remaining viable even when the chlorine content meets legal parameters, as described in this study. The resistance of enterococci can be acquired by their ability to form biofilms. These biofilms consist of a community of bacterial cells enclosed in a self-produced polymeric matrix that adheres to an inert or living surface. This film protects the enterococci from adverse action, making it difficult to be removed (Peter et al., 2012).

Seeing that the enterococci is part of the human and animal natural intestinal flora (Said et al., 2015), these bacteria have traditionally been used as indicators of fecal contamination of water (D'Ugo et al., 2018) because of their abundant presence in the feces of warm-blooded animals and long-term survival of species in the aquatic environment (D'Ugo et al., 2018; World Health Organization, 2018). Hence, fecal contamination is considered the leading cause of disturbances related to public health involving drinking water, reinforcing the need of quality care for this resource (Kishinhi et al., 2013). Moreover, the research on the enterococci can be used as a tool to control possible contamination of water sources, justifying further investigation (Rathnayake et al., 2011).

It is important to emphasize that not all species of enterococci have pathogenic potential. Notwithstanding, only two bacterial species, Enterococci faecium and Enterococci faecalis found in high concentrations, are related to human infections (Huycke et al., 1998). Although high doses are necessary to cause infection and few species of enterococci exhibit pathogenic potential, however, the presence of enterococci reinforce fecal contamination and, when their results of Antimicrobial Susceptibility Tests (ASTs) are taken into account, these results may represent a risk to human health, especially for children attending schools. 
The identification of isolated strains of enterococci revealed Enterococci faecium in two water samples of drinking fountains. The presence of Enterococci faecalis was also detected in three samples of water of kitchen faucets and in one sample of drinking fountain (Table 2). This detection of the enterococci species in the water samples was similar to other studies reported in different countries (Said et al., 2015). The test result can be explained by the ability of these species to survive in the environment (Alipour et al., 2014) and in contaminated water, since these species are most commonly found in the gut microbiota of animals and humans (Klein, 2003).

It must also be taken into consideration that the species of Enterococci faecium and Enterococci faecalis are highly resistant to antimicrobials (Rathnayake et al., 2011; Said et al., 2015), as evidenced in this study, where the isolated strains had similar behaviors, comprising a resistance to six antibiotics and intermediate sensitivity to one antibiotic (Streptomycin) of the nine antibiotics tested (Table 2). These results demonstrated that the drinking water destined for human consumption in the public schools might pose a risk for student's health since fecal contamination by enterococci species was confirmed. As enterococci are considered a source of genes with resistance to antimicrobials, they can easily be spread to other people. Therefore, emergence of enterococci antimicrobial resistance and its presence in school water systems suggest a situation of risk for students. There is also a possible correlation between strains present in hospitals with those isolated from water at school that must be considered.

Table 2. Antibiogram profile of the isolated enterococci in the water samples of public schools in the city of Curitiba, Brazil.

\begin{tabular}{|c|c|c|c|c|c|c|c|c|c|c|c|c|}
\hline \multicolumn{13}{|c|}{ School } \\
\hline \multirow{2}{*}{ Collection area } & \multicolumn{2}{|c|}{$10 * *$} & \multicolumn{2}{|c|}{$14 * *$} & \multicolumn{2}{|c|}{$16 * *$} & \multicolumn{2}{|c|}{$16 * *$} & \multicolumn{2}{|c|}{$17^{* *}$} & \multicolumn{2}{|c|}{$39 * *$} \\
\hline & \multicolumn{2}{|c|}{$\begin{array}{l}\text { Drinking } \\
\text { fountain }\end{array}$} & \multicolumn{2}{|c|}{$\begin{array}{c}\text { Kitchen } \\
\text { faucet }\end{array}$} & \multicolumn{2}{|c|}{$\begin{array}{l}\text { Drinking } \\
\text { fountain }\end{array}$} & \multicolumn{2}{|c|}{$\begin{array}{c}\text { Kitchen } \\
\text { faucet }\end{array}$} & \multicolumn{2}{|c|}{$\begin{array}{l}\text { Drinking } \\
\text { fountain }\end{array}$} & \multicolumn{2}{|c|}{$\begin{array}{c}\text { Kitchen } \\
\text { faucet }\end{array}$} \\
\hline $\begin{array}{c}\text { Species of } \\
\text { enterococci } \\
\text { antibiotics tested }\end{array}$ & \multicolumn{2}{|c|}{ E. faecium } & \multicolumn{2}{|c|}{ E. faecalis } & \multicolumn{2}{|c|}{ E. faecium } & \multicolumn{2}{|c|}{ E. faecalis } & \multicolumn{2}{|c|}{ E. faecalis } & \multicolumn{2}{|c|}{ E. faecalis } \\
\hline Ciprofloxacin $5 \mu \mathrm{g}$ & $32.9^{*}$ & $\mathrm{~L}$ & $33.1^{*}$ & $\mathrm{~L}$ & $30.0^{*}$ & $\mathrm{~L}$ & $31.25^{*}$ & $\mathrm{~L}$ & $31.35^{*}$ & $\mathrm{~L}$ & $32.4^{*}$ & $\mathrm{~L}$ \\
\hline Chloramphenicol $30 \mu \mathrm{g}$ & $21.0^{*}$ & $\mathrm{~L}$ & $21.2^{*}$ & $\mathrm{~L}$ & $19.8^{*}$ & $\mathrm{~L}$ & $17.4^{*}$ & M & $17.0^{*}$ & M & $19.3^{*}$ & $\mathrm{~L}$ \\
\hline Erythromycin $15 \mu \mathrm{g}$ & $0^{*}$ & $\mathrm{H}$ & $0^{*}$ & $\mathrm{H}$ & $0^{*}$ & $\mathrm{H}$ & $0^{*}$ & $\mathrm{H}$ & $0^{*}$ & $\mathrm{H}$ & $0^{*}$ & $\mathrm{H}$ \\
\hline Penicillin $10 \mu \mathrm{g}$ & $0^{*}$ & $\mathrm{H}$ & $0^{*}$ & $\mathrm{H}$ & $0^{*}$ & $\mathrm{H}$ & $0^{*}$ & $\mathrm{H}$ & $0 *$ & $\mathrm{H}$ & $0 *$ & $\mathrm{H}$ \\
\hline Rifampicin $5 \mu \mathrm{g}$ & $0^{*}$ & $\mathrm{H}$ & $0^{*}$ & $\mathrm{H}$ & $0^{*}$ & $\mathrm{H}$ & $0^{*}$ & $\mathrm{H}$ & $0^{*}$ & $\mathrm{H}$ & $0 *$ & $\mathrm{H}$ \\
\hline Tetracycline $30 \mu \mathrm{g}$ & $0^{*}$ & $\mathrm{H}$ & $0 *$ & $\mathrm{H}$ & $0^{*}$ & $\mathrm{H}$ & $0^{*}$ & $\mathrm{H}$ & $0^{*}$ & $\mathrm{H}$ & $0^{*}$ & $\mathrm{H}$ \\
\hline Ampicillin $10 \mu \mathrm{g}$ & $0^{*}$ & $\mathrm{H}$ & $0^{*}$ & $\mathrm{H}$ & $0^{*}$ & $\mathrm{H}$ & $0 *$ & $\mathrm{H}$ & $0^{*}$ & $\mathrm{H}$ & $0^{*}$ & $\mathrm{H}$ \\
\hline Gentamicin $120 \mu \mathrm{g}$ & $0^{*}$ & $\mathrm{H}$ & $0^{*}$ & $\mathrm{H}$ & $0^{*}$ & $\mathrm{H}$ & $0 *$ & $\mathrm{H}$ & $0^{*}$ & $\mathrm{H}$ & $0^{*}$ & $\mathrm{H}$ \\
\hline Streptomycin $300 \mu \mathrm{g}$ & $10^{*}$ & $\mathrm{H}$ & $9.9^{*}$ & $\mathrm{H}$ & $8^{*}$ & $\mathrm{H}$ & $7.4^{*}$ & $\mathrm{H}$ & $8^{*}$ & $\mathrm{H}$ & $7.4^{*}$ & $\mathrm{H}$ \\
\hline
\end{tabular}

Legend: *inhibition zone (mm). **Resistance. M: moderate; H: high; L: low; E: Enterococci.

The intrinsic resistance of enterococci to antibiotics used in clinical practice and the resistance to other antibiotics acquired after the consecutive emergence of multidrug-resistant strains make it difficult to treat infections in most cases (Peter et al., 2012; Said et al., 2015). Thus, regardless of the sanitizing products used and their concentrations, the treatment of water used in schools is compromised by the difficulty of eliminating enterococci. This scenario reflects an emerging public health problem that can be related to an increase in mortality, lengthier hospitalization time and health costs (Huijbers et al., 2015). 
In this study, of 40,649 students enrolled in schools, 17,078 were exposed to consumption of water that did not meet all the water quality standards of Brazilian law. This may represent a public health problem, especially in the presence of enterococci, as $25.34 \%(n=4,328)$ of these students could be ingesting water subject to fecal contamination, which was detected only after enterococci was employed as a complementary fecal indicator (Table 1). This finding is concerned with this public health problem because drinking water is an essential requirement for the health of children (Rahman et al., 2016).

In addition, children present relatively lower immunity than adults, making it necessary to adopt additional security measures to protect them from possible contact with pathogens transmitted through contaminated water (Marzano \& Balzaretti, 2013). Therefore, the results require larger control effort (chlorine dosage) and conventional water treatment, as well as reinforce the need to adopt other technologies for disinfection and to include study regarding other parameters of microorganisms to ensure water quality.

Moreover, implementation of a comprehensive and effective plan of water management that addresses criteria specifically for educational establishments is recommended. The water management plans should contain control procedures applied through monitoring routines. These routines need to be able to help workers identify areas that need improvement, ensuring that the criteria are effectively applied. The monitoring routine is considered an important tool to assess the most relevant characteristics of water quality and must be carried out in an integrated manner by using statutory and complementary indicators (Said et al., 2015).

\section{Conclusions}

The exclusive use of the legal parameters showed inadequate quality of drinking water in the public schools, demonstrating the need to assess the maintenance and the disinfection procedures performed water supply systems in schools. At the same time, the results showed that the drinking water destined for human consumption in the public schools probably posed a risk for students' health, since fecal contamination by enterococci was confirmed. Enterococci are considered a source of genes with resistance to antimicrobials, as well as easily spread to other people. This characteristic was observed in kitchen faucets and drinking fountains of the schools.

Additionally, fecal contamination was evidenced only after using another indicator of fecal contamination that is not required by current legislation. In addition, antibiogram studies reinforced the risk of water consumption, as contamination was detected, and the isolated bacteria were resistant to six antibiotics.

\section{Acknowledgements}

This article presented a part of the first author's Master degree study, and was funded by National Council for Scientific and Technological Development (in Portuguese Conselho Nacional de Desenvolvimento Cientifico e Tecnológico (CNPq), under process number 552448/2011-7. The first author also thanks the Secretary of Education of the State of Paraná for the partnership and also for all schools that participated in this study. The funding agencies had no participation in the study design, analysis or article writing. The authors would like to thank reviewer, Sidney Ann Pratt, Canadian, and the Academic Publishing Advisory Center (Centro de Assessoria de Publicação Acadêmica, (CAPA) - www.capa.ufpr.br) of the Federal University of Paraná (Universidade Federal do Paraná (UFPR) for English language assistance.

\section{References}

Alipour, M., Hajiesmaili, R., Talebjannat, M., \& Yahyapour, Y. (2014). Identification and antimicrobial resistance of Enterococcus spp. isolated from the river and coastal waters in northern Iran. TheScientificWorldJournal, 1-5, 287458. PMid:25525617. http://dx.doi.org/10.1155/2014/287458 
Ameme, D. K., Alomatu, H., Antobre-Boateng, A., Zakaria, A., Addai, L., Fianko, K., Janneh, B., Afari, E. A., Nyarko, K. M., Sackey, S. O., \& Wurapa, F. (2016). Outbreak of foodborne gastroenteritis in a senior high school in South-eastern Ghana: A retrospective cohort study. BMC Public Health, 16(564), 1-10. PMid:27411682. http://dx.doi.org/10.1186/s12889-016-3199-2

American Public Health Association - APHA. (1998). Standard methods for the examination of water and wastewater (20rd ed.). Washington: APHA.

American Public Health Association - APHA. (2012). Standard methods for the examination of water and wastewater (22rd ed.). Washington: APHA.

Ashbolt, N. J. (2015). Microbial contamination of drinking water and human health from community water systems. Current Environmental Health Reports, 2(1), 95-106. PMid:25821716. http://dx.doi.org/10.1007/s40572-014-0037-5

Bishankha, S., Bhatta, D. R., Joshi, D. R., \& Joshi, T. P. (2013). Assessment of microbial quality of chlorinated drinking tap water and susceptibility of Gram-negative bacterial isolates towards chlorine. Kathmandu Univ. J. Sci. Eng. Tech, 9(1), 222-229. http://dx.doi.org/10.3126/njst.v13i1.7456

Braeye, C. T. K., Wollants, K. S. E., Van Ranst, M., \& Verhaegen, J. (2015). A large community outbreak of gastroenteritis associated with consumption of drinking water contaminated by river water, Belgium, 2010. Epidemiology and Infection, 143(4), 711-719. PMid:25062494. http://dx.doi.org/10.1017/S0950268814001629

Brasil. Ministério da Saúde. Agência Nacional de Vigilância Sanitária. (2017, setembro 28). Consolidação das normas sobre as ações e os serviços de saúde do Sistema Único de Saúde (Portaria de Consolidação n ${ }^{5}$, de 28 de setembro de 2017). Diário Oficial [da] República Federativa do Brasil, Brasília. Retrieved in 2019, May 23, from https://www.normasbrasil.com.br/norma/portaria-de-consolidacao-5-2017_356387.html

Brasil. Ministério da Saúde. Secretaria de Vigilância em Saúde. Departamento de Vigilância das Doenças Transmissíveis. Coordenação Geral de Doenças Transmissíveis. (2019). Surtos de doenças transmitidas por alimentos: Informe 2018. Brasília. Retrieved in 2019, May 23, from https://portalarquivos2.saude.gov.br/images/pdf/2019/fevereiro/15/Apresenta----o-Surtos-DTA--Fevereiro-2019.pdf

Chowdhury, S. (2012). Heterotrophic bacteria in drinking water distribution system: A review. Environmental Monitoring and Assessment, 184(10), 6087-6137. PMid:22076103. http://dx.doi.org/10.1007/s10661-011-2407-x

Clinical and Laboratory Standards Institute - CLSI. (2011). Performance standards for antimicrobial susceptibility testing: Twentfirst information supplement: CLSI M100-S21. Wayne, PA: CLSI. Retrieved in 2019, May 23, from http://www.aeciherj.org.br/publicacoes/clsi.pdf

D’Ugo, E., Marcheggiani, Z., D’Angelo, A. M., Caciolli, S., Puccinelli, C., Giuseppetti, R., Marcoaldi, R., Romanelli, C., \& Mancini, L. (2018). Microbiological water quality in the medical device industry in Italy. Microchemical Journal, 136, $293-299$. http://dx.doi.org/10.1016/j.microc.2016.12.012

Diduch, M., Polkowska, Z., \& Namiesnik, J. (2016). The role of heterotrophic plate count bacteria in bottled water quality assessment. Food Control, 61, 188-195. http://dx.doi.org/10.1016/j.foodcont.2015.09.024

European Union. (1998). Council Directive 98/83/EC of 3 November 1998 on the quality of water intended for human consumption. Official Journal of the European Union (pp. 32-54), Brussels.

Fakayode, I. B., \& Ogunjobi, A. A. (2018). Quality assessment and prevalence of antibiotic resistant bacteria in government approved mini-water schemes in Southwest, Nigeria. International Biodeterioration \& Biodegradation, 133, 151-158. http://dx.doi.org/10.1016/j.ibiod.2018.07.004

Feng, P., Weagant, S. D., Grant, M. A., \& Burkhardt, W. (2002). BAM 4: Enumeration of Escherichia coli and the coliform bacteria. Silver Spring: FDA. Retrieved in 2019, May 23, from https://www.fda.gov/food/laboratory-methods-food/bam-4enumeration-escherichia-coli-and-coliform-bacteria\#conventional

Huijbers, P. M. C., Blaak, H., Jong, M. C. M., Graat, E. A. M., Vandenbroucke-Grauls, C. M. J. E., \& Husman, A. M. R. (2015). Role of the environment in the transmission of antimicrobial resistance to humans: A review. Environmental Science \& Technology, 49(20), 11993-12004. PMid:26355462. http://dx.doi.org/10.1021/acs.est.5b02566

Huycke, M. M., Sahm, D. F., \& Gilmore, M. S. (1998). Multiple-drug resistant enterococci: The nature of the problem and an agenda for the future. Emerging Infectious Diseases, 4(2), 239-249. PMid:9621194. http://dx.doi.org/10.3201/eid0402.980211

Ikonen, J., Pitkanen, T., Kosse, P., Ciszek, R., Kolehmainen, M., \& Miettinen, I. T. (2017). On-line detection of Escherichia coli intrusion in a pilot-scale drinking water distribution system. Journal of Environmental Management, 198(1), 384-392. PMid:28494427. http://dx.doi.org/10.1016/j.jenvman.2017.04.090

Kishinhi, S. S., Tchounwou, P. B., \& Farah, I. O. (2013). Molecular approach to microbiological examination of water quality in the Grand Bay National Estuarine Research Reserve (NERR) in Mississippi, USA. Environmental Health Insights, 7, 33-41. PMid:23761974. http://dx.doi.org/10.4137/EHI.S11455

Klein, G. (2003). Taxonomy, ecology and antibiotic resistance of enterococci from food and the gastro-intestinal tract. International Journal of Food Microbiology, 88(2-3), 123-131. PMid:14596985. http://dx.doi.org/10.1016/S0168-1605(03)001752

Marzano, M. A., \& Balzaretti, C. M. (2013). Protecting child health by preventing school-related foodborne illnesses:

Microbiological risk assessment of hygiene practices, drinking water and ready-to-eat foods in Italian kindergartens and schools. Food Control, 34(2), 560-567. http://dx.doi.org/10.1016/j.foodcont.2013.05.031

Meschede, M. S. C., Figueiredo, B. R., Alves, R. I. da S., \& Segura-Muñoz, S. I. (2018). Drinking water quality in schools of the Santarém region, Amazon, Brazil, and health implications for school children. Revista Ambiente \& Água, 13(6), e2218. http://dx.doi.org/10.4136/ambi-agua.2218 
Enterococci used as complementary indicator of fecal contamination to assess water quality from public schools in the city of Curitiba, Paraná, Brazil

Waideman, M. A. et al.

Morgan, C., Bowling, M., Bartram, J., \& Kayser, G. L. (2017). Water, sanitation, and hygiene in schools: Status and implications of low coverage in Ethiopia, Kenya, Mozambique, Rwanda, Uganda, and Zambia. International Journal of Hygiene and Environmental Health, 220(6), 950-959. PMid:28539190. http://dx.doi.org/10.1016/j.ijheh.2017.03.015

Ngwenya, B. N., Thakadu, O. T., Phaladze, N. A., \& Bolaane, B. (2018). Access to water and sanitation facilities in primary schools: A neglected educational crisis in Ngamiland district in Botswana. Physics and Chemistry of the Earth Parts A/B/C, 105, 231-238. http://dx.doi.org/10.1016/j.pce.2018.03.006

Park, J., Kim, J. S., Kim, S., Shin, E., Oh, K. H., Kim, Y., Kim, C. H., Hwang, M. A., Jin, C. M., Na, K., Lee, J., Cho, E., Kang, B., Kwak, H., Seong, W. K., \& Kim, J. (2018). A waterborne outbreak of multiple diarrhoeagenic Escherichia coli infections associated with drinking water at a school camp. International Journal of Infectious Diseases, 66, 45-50. PMid:29031605. http://dx.doi.org/10.1016/j.ijid.2017.09.021

Peter, A., Mathew, J., \& Zacharia, S. (2012). Antibiotic resistant enterococci from drinking water sources. Asian Journal of Pharmaceutical and Clinical Research, 5(3), 58-160. Retrieved in 2019, May 23, from https://innovareacademics.in/journal/ajpcr/Vol5Suppl3/1195.pdf

Proctor, C. R., \& Hammes, F. (2015). Drinking water microbiology - from measurement to management. Current Opinion in Biotechnology, 33, 87-94. PMid:25578740. http://dx.doi.org/10.1016/j.copbio.2014.12.014

Rahman, A., Hashem, A., \& Nur-A-Tomal, S. (2016). Potable water quality monitoring of primary schools in Magura district, Bangladesh: Children's health risk assessment. Environmental Monitoring and Assessment, 188(12), 680. PMid:27864776. http://dx.doi.org/10.1007/s10661-016-5692-6

Rathnayake, I., Hargreaves, M., \& Huygens, F. (2011). SNP diversity of Enterococcus faecalis and Enterococcus faecium in a South East Queensland waterway, Australia, and associated antibiotic resistance gene profiles. BMC Microbiology, 11(201), 247-252. PMid:21910889. http://dx.doi.org/10.1186/1471-2180-11-201

Said, L. B., Klibi, N., Lozano, C., Dziri, R., Slama, K. B., Boudabous, A., \& Torres, C. (2015). Diversity of enterococcal species and characterization of high-level aminoglycoside resistant enterococci of samples of wastewater and surface water in Tunisia. The Science of the Total Environment, 530-531, 11-17. PMid:26026404. http://dx.doi.org/10.1016/j.scitotenv.2015.05.091

Sanches, S. M., Muniz, J. M., Passos, C., \& Vieira, E. M. (2015). Chemical and microbiological analysis of public school water in Uberaba Municipality. Revista Ambiente \& Água, 10(3), 530-541. http://dx.doi.org/10.4136/ambi-agua.1464

United States Environmental Protection Agency - USEPA. (2019). Drinking water requirements for states and public water systems. Washington: USEPA. Retrieved in 2019, May 23, from https://www.epa.gov/dwreginfo/revised-total-coliform-rule-andtotal-coliform-rule

Wallender, E. K., Ailes, E. C., Yoder, J. S., Roberts, V. A., \& Brunkard, J. M. (2014). Contributing factors to disease outbreaks associated with untreated groundwater. Ground Water, 52(6), 886-897. PMid:24116713. http://dx.doi.org/10.1111/gwat.12121

World Health Organization - WHO. (2015a). Improving nutrition outcomes with better water, sanitation and hygiene: Practical solutions for policies and programmes. Geneva: WHO. Retrieved in 2019, May 23, from http://www.who.int/water_sanitation_health/publications/washandnutrition/en/

World Health Organization - WHO. United Nations Children's Fund - UNICEF. (2015b). Progress on sanitation and drinking water 2015 update and MDG assessment. Geneva: WHO. Retrieved in 2019, May 23, from http://www.who.int/water_sanitation_health/monitoring/jmp-2015-update/en/

World Health Organization - WHO. (2018). A global overview of national regulations and standards for drinking-water quality. Geneva: WHO. Retrieved in 2019, May 23, from https://apps.who.int/iris/bitstream/handle/10665/272345/9789241513760eng.pdf?ua=1

Financiamento: Ministério da Ciência, Tecnologia e Inovação Conselho Nacional de Desenvolvimento Científico e Tecnológico (CNPq), Processo n 552448/2011-7. 